\title{
ELECTORAL RULES \\ OR ELECTORAL LEVERAGE? \\ Explaining Muslim Representation \\ in England
}

\author{
By RAFAELA M. DANCYGIER*
}

\begin{abstract}
T ARGE-SCALE immigration has significantly altered the religious and ethnic makeup of advanced democracies. Yet the diversity encountered in city streets is not always reflected in the political sphere; we observe substantial variation in the political representation of immigrant-origin minorities across countries and groups. Processes of electoral inclusion are also uneven within countries. While ethnic minorities are well represented in some cities, they appear to confront daunting hurdles when attempting to enter town halls in others. ${ }^{1}$ Such variation has in turn been linked to important sociopolitical outcomes. Increases in minority descriptive representation, for example, have been shown to lead to more positive attitudes toward minority groups, ${ }^{2}$ to a lower incidence of antistate violence on the part of minorities, ${ }^{3}$ and to better substantive representation of minority interests. ${ }^{4}$

In their efforts to account for variation in the electoral representation of minorities, political scientists have examined the role of electoral institutions. Yet, it can be difficult to isolate the effect of these rules on the election of minority groups in democracies where there
\end{abstract}

\footnotetext{
*For helpful comments, I thank Mark Beissinger, Michael Donnelly, Rob Ford, Dan Hopkins, Raymond Hicks, Alex Kuo, David Laitin, Evan Lieberman, Yotam Margalit, Quinton Mayne, Tali Mendelberg, Jessica Trounstine, Kåre Vernby, workshop participants at Princeton University, University of California Berkeley, and the Juan March Institute, three anonymous reviewers, and the editors. For financial support, I am grateful to the Luce Foundation and to Princeton University.

${ }^{1}$ On variation in the political representation of immigrant-origin minorities, see, for example, Trounstine and Valdini 2008; Bird, Saalfeld, and Wüst 2011; Bloemraad 2013; Givens and Maxwell 2012; and Maxwell 2012.

${ }^{2}$ Chauchard forthcoming; Hajnal 2007.

${ }^{3}$ Dancygier 2010.

${ }^{4}$ Chattopadhyay and Duflo 2004; Tatari 2010; but see Cameron, Epstein, and O'Halloran 1996; and Dunning and Nilekani 2013.
}

World Politics 66, no. 2 (April 2014), 229-63

Copyright (C) 2014 Trustees of Princeton University doi: 10.1017/S0043887114000021 
is variation across a host of cultural, legal, political, and demographic areas. Research seeking to explain the election of immigrant-origin minorities in Western democracies has paid attention to the broader national and local opportunity structures said to influence the political behavior of both immigrant minorities and established, nonimmigrant elites. These include macrovariables such as citizenship and immigration regimes; mesolevel factors such as party systems and campaign finance laws; and variables at the microlevel, such as the demographic and behavioral traits of immigrant groups. ${ }^{5}$ Likewise, with regard to the election of women, accounts have identified the broader political system (for example, the electoral and party system and the political culture) and the organization and ideology of political parties, in addition to gender roles and the socialization of women as some of the important drivers of female representation. ${ }^{6}$

With so many moving parts, it is difficult to identify which forces influence the representation of minority groups and, more specifically, what role electoral rules play in this process. As Norris points out, electoral rules are of special importance, "but it would be misleading to see this factor in isolation from its cultural and political milieux," as various factors interact with these rules to yield distinct patterns in representation. ${ }^{7}$ Additional complexity arises when differences in minority political mobilization prompt reforms in electoral rules in some contexts but not in others, thereby making it difficult to disentangle the extent to which minority political activity or electoral rules cause variation in representation. ${ }^{8}$ If large, well-organized minority groups are more likely to push through changes in electoral laws than are smaller, less powerful groups, researchers may overestimate the effect of these rules on representation.

This article addresses some of the challenges scholars typically confront when estimating how electoral institutions shape minorities' chances of accessing legislatures. I examine the effect of electoral rules - single-member versus multimember races - on the representation of Muslims in England covering a set of municipalities in which rules vary across and within localities over time. (This variation is unrelated to minority political behavior.) To do so, I assembled a data set

\footnotetext{
${ }^{5}$ For a model that includes these macro-, meso-, and microlevel variables, see Bird, Saalfeld, and Wüst 2011. See also Bloemraad 2006; Hochschild and Mollenkopf 2009; and Trounstine and Valdini 2008.

${ }^{6}$ Kittilson 2006; Lawless and Fox 2010; Norris 1993.

${ }^{7}$ Norris 1993, 314. On this general point, see also Bird, Saalfeld, and Wüst 2011; Bloemraad 2013; and Norris 2004.

${ }^{8}$ Cf. Engstrom and McDonald 1986.
} 
of English local elections from 2002 to 2010 containing more than 42,000 observations at the candidate level. Unlike most studies examining descriptive representation at the local level, these data not only contain information on the winning candidates but they also include information on each competing candidate, allowing me to analyze differences both in election outcomes and in the selection of candidates by local parties. ${ }^{9}$

Existing research has hypothesized that multimember races raise the share of elected minorities when compared with single-member contests, because they allow party leaders to balance the slate. The winnertake-all nature of single-member elections rules out this possibility and makes it more likely that parties will run candidates belonging to dominant majority groups. The evidence in support of this logic has, however, been mixed. ${ }^{10}$

This article finds that electoral rules matter, but in more subtle ways than is commonly hypothesized. I find that the rules under study here do not influence the share of elected representatives who are Muslim across municipalities. Rather, I find that demographic variables influencing Muslims' electoral leverage-such as the size of the Muslim population and its spatial concentration-are much more central. In examining the selection stage, I find that Muslims confront different contexts across electoral institutions. First, when only one seat is up for election, selection becomes more likely as seats become less desirable and have less chance of winning. Here again, however, electoral leverage matters: this effect reverses as the size of the Muslim population and its associated electoral strength rises. Second, in a given contest, Muslims are indeed more likely to enter multimember races ${ }^{11}$ than they are to enter single-member races; the more seats are in play, the more likely it is that a Muslim will be selected. However, in single-member elections, parties balance the slate over the course of several elections, leading to similar election outcomes across electoral rules. Taken together, these findings show that although overall election outcomes are similar, selection dynamics reveal that parties respond strategically to electoral institutions. The results further demonstrate that the local electoral clout of Muslims is paramount: the effect of institutions

\footnotetext{
${ }^{9}$ Research studying the election of women has more often also included information on candidates than has research on ethnic minority representation (see below).

${ }^{10}$ See, for example, Norris 2004; Welch and Studlar 1990; and sources cited in the Theory section below.

${ }^{11}$ In the sample used here, multimember races have three open seats, and voters have three votes. Voters do not have to use all three votes. They can allocate votes across candidates, but they cannot award a candidate more than one vote. The three candidates with the most votes win.
} 
and the potential for institution-based discrimination largely depend on the size of the local Muslim population and the votes it can deliver at both the election and the selection stages.

These findings contribute to existing research on minority representation in several ways. First, by studying patterns of minority representation in contexts where electoral institutions change within and across locations for reasons unrelated to minority group politics, in one national setting and with reference to one minority group, we can be more confident that the reported institutional effects are indeed at work. Second, this research design allows us to better understand how variation in microlevel group characteristics that scholars often assume to be important $\mathrm{t}^{12}$ - size, concentration, and fractionalization-can, on its own and in conjunction with electoral rules, account for variation in representation.

Third, the article advances our understanding of minority representation by improving our understanding of selection - the first stage in the representation process. Despite its obvious importance as the initial entry point, this area still remains vastly understudied in the comparative research of ethnic minority representation. ${ }^{13}$

Fourth, in shedding light on the election and selection of Muslims in England, the article adds to our knowledge of the representation of England's - and Europe's - fastest-growing ethnoreligious minority group. Commenting on the presence of Muslim politicians in local and national government in England, an East London Muslim councillor declared that "the paucity of Muslim representation is simply scandalous." Muslim office seekers, this councillor lamented, face "a high level of exclusion from ... the political process." ${ }^{14}$ Others conclude similarly that the entry of Muslims into local electoral politics in England is marked by discrimination and exclusion. ${ }^{15}$ These portrayals are at odds, however, with those that depict a Muslim electorate that is actively engaged in local politics as both voters and candidates and that has produced a number of local councillors across the country. ${ }^{16}$ There is to date little work that allows us to adjudicate between these accounts. While

\footnotetext{
${ }^{12}$ See, for example, Bird, Saalfeld, and Wüst 2011; and Maxwell 2012.

${ }^{13}$ On this point, see Bird, Saalfeld, and Wüst 2011, 16; and Bloemraad 2013. For an exception, see Norris and Lovenduski 1995.

${ }^{14}$ Murshid 2004, 26-27.

${ }^{15}$ Purdam 1998.

${ }^{16}$ See, for example, Geddes 1993; Saggar 1998; Anwar 2001; Tatari 2010; and Maxwell 2012. These authors do not all focus on Muslims; they focus on South Asian or Pakistani Britons, many of whom are Muslim.
} 
research is accumulating about Muslim voters and officeholders, ${ }^{17}$ we still know relatively little about what determines their selection as candidates and their election. As the integration of Muslims in England and in Europe continues to be a highly salient and controversial issue, ${ }^{18}$ this article seeks to gain traction regarding one aspect of integration: Muslims' inclusion in the electoral arena.

The rest of the article is organized as follows. I first provide a brief overview of the role of ethnic and religious minorities in English local elections and then discuss theories linking the electoral rules under study here to minority representation. I next introduce the data and present the empirical findings, beginning with results at the local authority level before turning to analyses at the level of the ward party. The concluding section addresses some of the article's implications for the electoral inclusion of minorities more generally and across comparative contexts.

\section{ENGLish Local Elections AND ETHNic AND Religious Minorities}

The concept of descriptive representation embodies the idea that the life experiences or ascriptive attributes of elected representatives are typical of the wider society they are elected to represent. Normative theorists have tended to be skeptical of the idea that descriptive representation is needed to adequately represent group interests, and empirical evidence linking descriptive to substantive representation has been mixed. That said, there is also support for the concept. ${ }^{19}$ Mansbridge argues that descriptive representation can advance policy goals by improving communication and deliberation, especially in settings of mistrust. ${ }^{20}$ She also contends that the election of members of groups that have faced discrimination or exclusion creates a greater sense of these groups' "ability to rule" and furthermore enhances perceived democratic legitimacy. Based on these criteria, ensuring the descriptive representation of Muslims - a group that has experienced discrimination and is viewed with mistrust by segments of the majority population—should

\footnotetext{
${ }^{17}$ Brouard and Tiberj 2005; Heath et al. 2011; Klausen 2005; Laurence 2012; Maxwell 2010; Sinno and Tatari 2009; Tatari 2010.

${ }_{18}$ On this topic, see Adida, Laitin, and Valfort 2010; Bleich and Maxwell 2012; Ford 2011; Helbling 2012; Modood 2003; Saggar 2009.

${ }^{19}$ For a critical appraisal, see Pitkin 1967; and for a more positive view under conditions of intergroup trust, see Phillips 1995.

${ }^{20}$ Mansbridge 1999.
} 
be a worthy pursuit, regardless of substantive policy achievements. Additionally, recent evidence indicates that the election of Muslim councillors in Greater London does promote policies favored by Muslims. ${ }^{21}$ Moreover, additional salient concerns — such as police surveillance and other forms of discrimination-are more likely to be addressed when Muslim elected officials can act as local mediators. ${ }^{22}$ Uncovering the forces that cause variation in the election of Muslim candidates should therefore be of interest to those who care about the quality of representation generally and about the political integration of Muslims specifically.

Substantive as well as methodological reasons make England a good case to explore the election of Muslim candidates to local office. First, numbering 1.5 million (or just over 3 percent of the population) in 2001 and 2.6 million (or 5 percent of the population) in 2011, ${ }^{23}$ Muslims in England belong to the country's second largest, after Christianity, and fastest-growing religion. Depending on one's conceptualization, they do not necessarily represent one unified group, but may identify as English, Britons, Pakistanis, Bangladeshis, Indians, Africans, Arabs, Kashmiris, or other subnational or nonnational groupings. In the empirical tests I examine specifically whether such cleavages have an impact on election outcomes. However, due to both external events and internal processes, the salience of Muslims' religious identity has risen above that of other identities during the course of the past decade. When asked whether they think of themselves first as Muslim or as black or Asian (two of the ethnic labels commonly used in official classifications), only 6 percent of Muslim respondents chose the latter two compared, as compared with 60 percent who prioritized their religion (34 percent said they identified equally as Muslim and as black or Asian). ${ }^{24}$ Further, scholars have debated the extent to which Muslims are successfully integrating into British society and politics. ${ }^{25}$ As stated at the outset, observers differ in their assessments of English Muslims' experiences in local politics, with accounts of exclusion existing alongside more optimistic appraisals. ${ }^{26}$ Since public debate has-rightly or

\footnotetext{
${ }^{21}$ Tatari 2010.

${ }^{22}$ On the importance of local elected officials in fashioning immigrant-state relations, see Dancygier 2010. On the role of government involvement at the local level in addressing grievances of British Muslims, see also Saggar 2009.

${ }^{23}$ The analyses below are based on 2001 data; 2011 local-level census data were not available when this article was completed.

${ }^{24}$ These figures are based on the 2010 Ethnic Minority British Election Study available at http:// bes2009-10.org/.

${ }^{25}$ For contrasting views, see Joppke 2009; and Maxwell 2010.

${ }^{26}$ For example, Geddes 1998; Le Lohé 1998; Tatari 2010.
} 
wrongly - identified the integration of British and European Muslims as a central issue, it is valuable to undergird this debate with empirical knowledge.

From a methodological perspective, one reason for studying England is that local electoral rules vary across as well as within local authorities over time, and I exploit the fact that a set of local authorities switched electoral rules from multimember districts (MMD) to single-member districts (SMD) for reasons that are exogenous to minority political behavior. This change gives us greater confidence when estimating the effect of electoral rules on election and selection outcomes, especially when compared with studies in which election law reforms occurred precisely to promote minority representation. In the latter cases, it may be that unobserved variables related to minority political behavior cause both increased minority representation and a change in rules, making it more difficult to estimate the effect of such rules on representation. As Grofman has noted in the context of the U.S.: "[C]ities which change from at-large to ward elections are ipso facto more likely to be characterized by a minority political organization of some strength which will be likely to generate greater minority representation under any electoral system." 27

Ethnic minorities, including Muslims, have been active participants in English local politics for several decades now. Many ethnic minority residents immigrated as citizens of the Commonwealth and, as such, were entitled to vote and stand in local elections from the day they arrived. While rates of descriptive representation used to lag behind those of the white majority population, recent years have witnessed significant improvements. Indeed, among some groups, especially those hailing from the Indian subcontinent, turnout has at times exceeded that of the native, white population, and representation rates reflect population shares. ${ }^{28}$ As many Muslims living in England trace their origins to Pakistan and Bangladesh, relatively high levels of representation apply to this group as well. In the sample of local authorities used here (see below for more detail), Muslims constitute 6.28 percent of the population and with 698 elected candidates they constitute 5.73 percent of all elected candidates. Returning to the debate about Muslim political incorporation referred to above, these figures suggest that at least when it comes to descriptive representation on local councils, Muslims lag behind by only a bit. As I will demonstrate, however, parity in numbers does not necessarily imply parity in treatment.

${ }^{27}$ Grofman 1982, 6, cited in Engstrom and McDonald 1986, 214, emphasis in original.

${ }^{28}$ Le Lohé 1998. 
The advancement of Muslim candidates is in part due to the institutions that govern English local elections. In the three main parties - Labour, the Conservatives, and the Liberal Democrats-local party institutions above the level of the ward (covering the authority or parliamentary constituency, for example) usually approve a panel of potential candidates, but the local party (typically at the ward level) is charged with selecting council candidates. The national party leaderships are generally not consulted in this process. Though local party leaderships can vet and veto candidates, local residents who join the ward party are involved in the selection of candidates. ${ }^{29}$ Local party elites thus act as initial gatekeepers, but party members also have a say about who stands in elections. In the Labour Party (the party of choice for the majority of Muslim voters and candidates), for example, a local party committee first decides whether potential candidates are "suitable" to compete for selection, a decision that the party's rule book considers a "matter of judgment." 30 However, once nominations are approved, ward party members, rather than party elites, vote on the selection of candidates who run in ward elections. ${ }^{31}$

Studies have remarked on the ability of Muslim political activists to recruit new party members and to urge fellow Muslims to vote en bloc to ensure the selection and election of a favored candidate. Loyalties based on kin and clan may be called upon in election campaigns and can advance or doom political enterprises. Aggregate election data lend support to the mobilizational role of these networks: Muslim registration and turnout rise significantly as their share in the local population increases. ${ }^{32}$ In the past, such mobilization often benefited the election of non-Muslim candidates who would rely on Muslim community leaders to get out the vote in the ward's party selection meetings and during elections. More recently, it is Muslim candidates themselves who have reaped the benefits, a change that non-Muslim party members have occasionally resisted. The political establishment has at times challenged the selection of Muslim candidates, and Muslim office seekers whose quests for nomination or selection failed have in turn brought cases of racial discrimination to employment tribunals. ${ }^{33}$

${ }^{29}$ Copus 2004; Leach 2006.

${ }^{30}$ Labour Party 2008, 89.

${ }^{31}$ Liberal Democratic and Conservative candidates are also selected by local party members (Ali and O'Cinneide 2002; Copus 2004). Copus 2004, 74, considers the differences in selection procedures across parties to be "slight." The main difference, he notes, is that while Conservative and Liberal Democratic practice may at times depart somewhat from party guidelines, this is less likely to be the case for Labour. The analyses below at the ward party level include party fixed effects.

${ }^{32}$ Fieldhouse and Cutts 2008.

${ }^{33}$ Garbaye 2005; Eade 1989; Solomos and Back 1995. 
While electoral institutions are thus comparatively open to minority candidates in theory, Muslims have encountered discrimination in practice, and the selection process can be quite contentious. Some have charged that it is especially difficult for Muslims to be selected to run in safe seats that are predominantly white. ${ }^{34}$ Across the country, surveyed Labour and Tory Party members were, on average, more likely to think that "black or Asian" candidates would lose rather than gain votes in their parliamentary constituency. ${ }^{35}$ Regardless of whether such beliefs are due to members' own prejudice or due to the prejudice they attribute to local electorates, they may act to thwart minority representation. However, as I demonstrate below, parties do not act indiscriminately: unfavorable placement varies systematically by electoral rule and Muslim electoral strength.

Finally, on occasion, Muslim candidates have been accused of engaging in fraudulent activities relating to the recruitment of Muslim members. Claims of "ethnic entryism"- the pursuit of party membership to manipulate selection outcomes without necessarily abiding by the values of the party - have contributed to strained relations in some locales. Such charges have tended to arise when non-Muslim politicians were deselected and replaced by candidates endorsed by Muslims. These defeated politicians have charged the "Muslim Mafia" with engineering candidate selections via corrupt practices. ${ }^{36}$

To sum up, Muslims have made important gains in local representation over the years, but along the way they have encountered a political establishment that has not always welcomed these advances. Below I examine whether and how electoral institutions might influence these patterns.

\section{Theory: Electoral Rules and the Election of Minorities TO LOCAL LEGISLATURES}

In England candidates in local elections are elected at the ward level in single-member or multimember elections according to plurality rule. ${ }^{37}$ Ward-level elections generally provide an electoral edge to geographically concentrated groups. In at-large elections, by contrast, the entire city forms an electoral arena, thereby diluting potential minority voting strength when groups are spatially segregated. Scholars have therefore found that concentrated minority groups are more likely to elect one

\footnotetext{
${ }^{34}$ Purdam 1998.

${ }^{35}$ Norris, Geddes, and Lovenduski 1992.

${ }^{36}$ Geddes 1998; Le Lohé 1998.

${ }^{37}$ The average ward population size in the sample is 12,499 .
} 
of their own in single-seat, ward-level elections than they are in multimember, at-large contests. ${ }^{38}$

However, when group size relative to the electoral arena is held constant-for instance, because groups are not spatially concentrated or because the size of geographic areas remain unchanged - studies have suggested that MMD contests may be more beneficial for the election of underrepresented groups. ${ }^{39}$ Here, party leaders may exercise a kind of "affirmative action" when placing minority candidates on the ballot. Additionally, leaders may hope that a balanced ticket will be attractive to new voting blocs in the electorate. As Welch and Studlar note with respect to the selection of women: "[P]arty leaders can broaden their party's appeal by slating women along with men in multi-member systems, when, because of their own prejudice or fear of voters' prejudices, they would not slate a woman as the sole candidate. ${ }^{20}$ Party leaders may also be more willing to absorb potential losses associated with a minority candidate if that candidate is not the only one in the running. By contrast, the winner-take-all nature of SMD elections hampers reaching out to minorities in this way. When only one seat is up for grabs in a given election, balancing the ticket is not an option, and strategic considerations about what kind of candidate will most likely win take center stage.

Though existing research has made strong theoretical claims about why MMD elections enhance the election of women and ethnic minorities, the empirical evidence has been mixed. Examining the election of females to state legislatures in fourteen US states, Darcy, Welch, and Clarke find that women are more likely to get elected when multiple seats are being contested. Matland and Brown, King, and Bullock have come to similar conclusions. ${ }^{41}$ However, others have challenged the idea that MMDs are positively linked to the election of women, noting that effects are spurious or variable across cases. ${ }^{42}$ For instance, when studying the effect of district magnitude on female representation in subnational legislatures in the US and Britain, Welch and Studlar do not find that multimember districts systematically enhance females' chances and speculate that district magnitude plays a larger role in national elections than it does in local elections. ${ }^{43}$ Likewise, when com-

\footnotetext{
${ }^{38}$ For example, Engstrom and McDonald 1986; Marschall, Ruhil, and Shah 2010; Trounstine and Valdini 2008.

${ }^{39}$ For example, Rule 1987; Matland and Brown 1992.

${ }^{40}$ Welch and Studlar 1990, 396.

${ }^{41}$ Bullock 2010; Darcy, Welch, and Clarke 1985; King 2002; Matland and Brown 1992.

${ }^{42}$ Bullock and Gaddie 1993; Matland 1993; Welch and Studlar 1990.

${ }^{43}$ Welch and Studlar 1990. On national elections, see, for example, Rule 1987.
} 
paring across a set of Western democracies, Bloemraad finds limited evidence that multimember systems boost the election prospects of ethnic minorities to national parliaments. ${ }^{44}$

These mixed results may be due to the fact that some studies employ bivariate regressions, ${ }^{45}$ which may distort findings if district magnitude is correlated with other factors, such as, for example, urbanization, that influence the election of minorities. Other inconsistencies may arise because political units - cities, states, and especially countries - vary in aspects that are unobserved or not included in the analyses, and these factors may interact with or overwhelm the effects of electoral rules. ${ }^{46}$ Ruedin argues, for instance, that attitudes toward minority groups trump electoral institutions in explaining ethnic minority representation across countries. ${ }^{47}$

Returning to the present study, according to the theoretical propositions laid out above (and given one national setting that holds constant a number of potentially confounding variables), we may expect more Muslims to get elected in multimember elections. However, given that Muslims - unlike women - are spatially concentrated, a balanced ticket may generate additional votes in only a small number of wards. Moreover, if we assume that the average English voter (or party leader) harbors more prejudice against Muslims than against women, the potential trade-off between appealing to an extra segment of the electorate on the one hand while hoping to retain existing voters on the other (holding turnout across groups constant) is sharpened. To the extent that this trade-off is more pronounced in SMD contests, MMD elections should nevertheless still raise the number of Muslim candidates.

Furthermore, given that the winner takes all in single-member races, competition for a spot on the ticket may be fiercer in those circumstances. One common complaint of minority candidates is that when they do run, they are often placed in "no hope" seats. ${ }^{48}$ This unfavorable placement should be more prevalent when only one seat is up for election, as party leaders and members may not want to give up a desirable seat when that seat is the only one being contested. As the discussion above has shown, however, Muslims have been quite active in pursuing ward party memberships. These effects should thus be conditional on the size of the Muslim electorate. When the Muslim population is

\footnotetext{
${ }^{44}$ Bloemraad 2013.

${ }^{45}$ For example, Darcy, Welch, and Clarke 1985; King 2002.

${ }^{46}$ For a discussion of some of these issues, see Matland and Brown 1992; Norris 1993; and Bullock 2010.

47 Ruedin 2009

${ }^{48}$ Ali and O'Cinneide 2002; Murray 2008.
} 
sizable, Muslims will be more likely to be able to influence selection processes as party members.

There are also reasons to believe that single-member districts are beneficial for electing minority candidates. In the case of SMD races, voters whose favored party is running a Muslim candidate but who are not enthusiastic about electing such a candidate would have to vote against their party or abstain if they followed their religiously based preferences. Having only one vote, electors may be reluctant to do so. Anticipating this behavior, parties may not be too concerned about running a Muslim candidate, especially in a country like England, where partisan loyalties tend to be strong. Although much of the literature on ethnic minority representation presumes that voters are more likely to cast ballots for candidates of their own ethnic group, ethnicity may be much less relevant when party loyalty is strong, and, by implication, electoral rules may not figure as prominently in parties' selection strategies. ${ }^{49}$

Summing up, though empirical findings are mixed due to the difficulty of isolating institutional effects, most theoretical accounts assume that multimember elections should lead to higher shares of ethnic minority representatives. The size of the minority population and its associated electoral clout should, however, condition these effects.

\section{DATA}

One reason why there have been few studies on the determinants of minority descriptive representation in European municipalities is the paucity of data. Unlike in the US, where databases of local-level, overtime minority representation exist, there are no such sources in $\mathrm{Eu}-$ rope. To gather information on the ethnic or religious backgrounds of minority populations, researchers have sent out questionnaires to city councils. ${ }^{50}$ One potential limitation of such an approach is that the information obtained is generally limited to the year of data collection; furthermore, city councils have varied in their response rates (perhaps in ways that are not unrelated to the degree of minority representation). Another approach, and the one pursued here, uses the first and last names of candidates to identify their religious backgrounds. ${ }^{51}$ The

\footnotetext{
${ }^{49}$ For accounts that stress the role of candidate ethnicity in countries with less developed party systems, see Horowitz 1985, 319-32; Chandra 2004; Posner 2005. In US cities racially polarized voting may be facilitated by the fact that local elections are often nonpartisan (for example, Trounstine and Valdini 2008). For a contrasting finding in the French context, see Brouard and Tiberj 2011.

${ }^{50}$ For example, Geisser 1997.

${ }^{51}$ See, for example, Jacobs, Martiniello, and Rea 2002; and Sinno and Tatari 2009.
} 
disadvantage of this approach is that there will likely be some error. Names of some minority councillors may be indistinguishable from those of the majority population, while some members of the majority population may have names that are associated with minority ethnicities. The advantage of this strategy, however, is that researchers can make use of a wide range of data, covering a number of years and including successful as well as failed candidates. This study employs a software program (Onomap) that was developed to identify the ethnic, geographic, linguistic, and religious backgrounds of residents living in the UK. ${ }^{52}$ Validation procedures indicate that Onomap's coding of religious affiliation produces very accurate results. ${ }^{53}$

The election data are collected at the level of the candidate and are derived from a variety of sources. ${ }^{54}$ In most cases, observations include only last names and first initials of candidates. To increase the reliability of the coding results, I added candidates' first names for each observation, consulting Web sites dedicated to disseminating English election information or contacting local authorities directly. I have collected and coded data on all candidates, not just on those who get elected. This allows me to gain additional insights about the nature of electoral competition in contests that include minority candidates. Finally, observations were geo-coded so that demographic and other contextual variables could be added.

The resulting data set covers seven election years (2002, 2003, 2004, 2006, 2007, 2008, and 2010) and sixty-eight local authorities, or boroughs. It contains 42,650 candidate-level observations; data on 26,574 ward parties; 6,784 ward-level elections, and 312 elections at the local authority level. I selected these authorities on the basis of their electoral formula. Specifically, I included the thirty-two boroughs

\footnotetext{
${ }^{52}$ For a detailed explanation of Onomap's methodology, see Lakha, Gorman, and Mateos 2011; and Mateos 2013. The author is aware of two other programs that identify religion on the basis of names (SANGRA and Nam Pehchan). However, these rely on dictionaries of South Asian names only, and the sample used here also includes Muslims who are not of South Asian origin.

${ }^{53}$ To validate the results, I conducted two tests. Using a sample of more than 14,000 candidates I coded the religious backgrounds of all candidates by relying on their names myself. The correlation between the two measures is $.99(p=.000)$. In another approach, I used data of councillors who are known to be Muslim. Eren Tatari generously provided a list of Muslim councillors representing London's thirty-two authorities between 2002 and 2010 whose religious backgrounds were verified by contacting local authorities directly. The correlation between my coding and that of Tatari is .90 ( $p=$ .000). Types of coding errors are almost evenly split: in 48.9 (51.1) percent of errors, I classify a candidate as Muslim (non-Muslim) even though they are non-Muslim (Muslim). Further, it is not the case that candidates that I fail to identify as Muslim due to their non-Muslim-sounding names, but who are indeed Muslim, do significantly better at the polls. The mean (median) vote shares of councillors that I record as non-Muslim but who are Muslim and vice versa are 47.0 and 47.1 (46.7 and 43.5) percent, respectively $(p=.975)$.

${ }^{54}$ See the supplementary material, Dancygier 2014.
} 
that constitute Greater London (which use MMD) and the thirty-six metropolitan boroughs (which switched from MMD to SMD) that can be found in regions across England (the North East, North West, the West Midlands, and Yorkshire and the Humber). Due to their urban nature, many of these local authorities contain Muslim population shares exceeding the national average. The present sample covers a population of 17.99 million, of whom 1.13 million, or 6.28 percent, are Muslim. In other words, over 70 percent of England's Muslims lives in the sixty-eight local authorities sampled here. At the authority level, the smallest and largest Muslim population shares are .17 and 36.4 percent, respectively. At the ward level, these figures are zero and 67 percent, respectively.

Authorities differ in the electoral rules that govern local elections. London boroughs elect candidates in three-member wards by plurality every four years (2002, 2006, and 2010 in the sample). Parties can run no more than three candidates, voters have three votes, and the three candidates that collect the highest number of votes win. Voters can use one, two, or all three votes, and they may allocate votes across candidates and parties, but they cannot award a candidate more than one vote. ${ }^{55}$ Wards in metropolitan boroughs, by contrast, elect one councillor (according to plurality rule) in each of three consecutive annual elections. Each ward is thus represented by three councillors, elected over the course of three years, with no elections taking place in the fourth year. In other words, while elections are single-member contests, wards are represented by more than one councillor with each being elected in separate elections. In 2004, however, metropolitan districts employed MMD elections whereby wards elected three candidates simultaneously using the same bloc vote system as in London. This permits us to test the effect of electoral rules on minority inclusion within wards and municipalities over time (the sample includes SMD elections in 2002, 2003, 2006, 2007, and 2008).

This change occurred due to the revision of ward boundaries. The Boundary Commission for England reviewed wards in the metropolitan boroughs between 2001 and 2003, with new ward boundaries taking effect in each authority in 2004. Importantly, these reviews were not initiated due to changes in minority behavior; nor were they driven by efforts to increase the representation of minorities. Rather, boundary changes took place in each metropolitan borough and were part of a routine, countrywide policy of electoral reviews in which every local

\footnotetext{
55 This system is known as the bloc vote; see Norris 2004, 48.
} 
authority in the country is considered at some point in time..$^{56}$ The main objective of these reviews is "to ensure that, within each principal local authority area, the number of electors represented by each councillor is as nearly as possible the same. ${ }^{\prime 7}$ The commission's mandate thus does not include working toward the equal representation of ethnic or religious minorities, and its guidelines make no mention of these groups. The distribution of Muslims within metropolitan boroughs is indeed nearly identical before and after the boundary changes. ${ }^{58}$ The first elections that operated according to the revised ward boundaries were held in 2004, when entire councils were up for election, with each ward electing three councillors. In 2006 wards in metropolitan boroughs returned to their regular practice of electing one councillor per election.

\section{Models And Results}

In addition to electoral rules, I include several other variables. The size of the Muslim population plays a significant role in electing fellow Muslims to the local council, due to both supply and demand side factors. ${ }^{59}$ Put simply, as the Muslim population grows, so should the pool of potential Muslim candidates. Further, since local residents influence the selection process as party members and influence election outcomes as voters, as the share of Muslims increases, so should the likelihood of electing a Muslim councillor. The qualitative evidence reviewed above certainly suggests that party leaders take candidate ethnicity into account and that Muslim party members have been crucial in selecting one of their own to run for office. If coethnicity also shapes voter behavior, increases in the Muslim population should also be associated with an increased number of Muslim candidates elected.

In addition to mere size, the distribution of the Muslim population across city wards should matter. If Muslims are dispersed across wards, they are less likely to provide the critical mass needed to elect a Muslim candidate. Conversely, when this group is concentrated in a handful of wards, the election of group members is a more realistic scenario, holding group size at the city level constant. There may also be an interactive effect: as segregation increases, the effect of SMD on the election

${ }^{56}$ Personal communication with Sam Hartley, Government Boundary Commission for England, June 2, 2010.

${ }^{57}$ The Electoral Commission 2002, 5.

${ }^{58}$ The mean (median) isolation index (a measure of spatial concentration, see below) is .115 (.079) before and $.120(.072)$ after the boundary changes $(p=.345)$.

${ }^{59}$ See Norris, Geddes, and Lovenduski 1992 on how supply and demand forces shape ethnic minority candidacies in the British parliament. 
of Muslim councillors could rise as well, if it is the case, for instance, that in segregated areas, SMD seats will reliably elect Muslim candidates but MMD seats may run a mix of candidates. ${ }^{60}$ To operationalize spatial segregation, I use the isolation index. This index may range from zero to one (in the sample it ranges from zero to .46) and calculates the probability of two members of the same group meeting one another in a ward. It therefore takes into account both the size of the minority population in the local authority as a whole and its dispersion across wards, both of which should matter in the election of city councillors. ${ }^{61}$

Another demographic feature pertains to the heterogeneity of the Muslim population itself. England's Muslims hail from a number of countries. Among Muslims in England born outside of the UK, 34 percent were born in Pakistan, 17 percent in Bangladesh, 17 percent in Africa, 11 percent in the Middle East, 8 percent in India, and 8 percent in other European countries (based on the 2001 census). Ethnic fragmentation has been shown to lower the chances of cooperative behavior in a number of settings and through a number of mechanisms, such as diverging preferences or lack of reciprocity. ${ }^{62}$ In the context of electoral politics, the proliferation of ethnic subgroups along linguistic or regional lines can similarly thwart the advancement of minority representation. ${ }^{63}$ Fragmentation across national-origin lines at the city level could impede efforts to elect Muslim candidates if, for example, wouldbe candidates are less likely to share information and resources about running and winning with coreligionists of different national backgrounds across wards (note that to run for council, candidates have to be resident in the local authority, but not in the ward, where the election takes place). Furthermore, in a setting where the majority of candidates decides to contest elections because they were approached by others to do so, ${ }^{64}$ and where Muslims have been shown to draw on kinship and clan networks, divisions within the Muslim electorate may reduce opportunities for the kind of exchanges and communication that facilitate election campaigns. To measure fragmentation along national-origin lines, I created an index of fractionalization based on the distribution

${ }^{60}$ Marschall, Ruhil, and Shah 2010; Trounstine and Valdini 2008.

${ }^{61}$ See Johnston, Poulsen, and Forrest 2005; Massey and Denton 1988; Trounstine and Valdini 2008. The formula is as follows: $\mathrm{I}=\sum \mathrm{i}(\mathrm{Mi} / \mathrm{M})(\mathrm{Mi} / \mathrm{Ti})$, where $(\mathrm{Mi} / \mathrm{M})$ measures the number of Muslims in a ward as a share of the authority's Muslims and (Mi/Ti) measures the number of Muslims as a share of the total population in a ward. The isolation index is appropriate because it takes into account the proportion of a group at the ward level, which is essential for assessing how group concentration matters electorally.

${ }^{62}$ For an overview as well as tests of these mechanisms, see Habyarimana et al. 2009.

${ }^{63}$ Lopez and Espiritu 1990.

${ }^{64}$ Rallings et al. 2010 find that two-thirds of candidates (54 percent of nonwhite candidates) were encouraged by others, rather than having made the decision to run entirely on their own. 
of national or regional origins of a city's foreign-born Muslim population. In the sample, the index ranges from .24 to .90 , with lower values indicating less fractionalization (see the supplementary material). ${ }^{65}$

I include a set of additional control variables. The vote share attained by the Labour Party at the borough level represents an aspect of the political opportunity structure that Muslim candidates confront (the results below are robust to the inclusion of the Conservatives' and the Liberal Democrats' vote share, as well as the vote share attained by parties other than these three main parties, including the BNP and Respect; see the supplementary material). ${ }^{66}$ I further include the election year and region fixed effects (the North East, the North West, the West Midlands, and Yorkshire and the Humber).

I first estimate city-level pooled regressions that include elections held under both types of electoral rules. The dependent variable in the authority-level regressions is the percentage of elected candidates who are Muslim in local authority elections (in the sample, it ranges from zero to 28 percent). ${ }^{67}$ This specification is similar to that adopted in most of the literature on city-level minority representation cited above. I next estimate the effect of electoral rules using a difference-indifferences $(\mathrm{DiD})$ specification. To gain a better understanding of how rules affect local party behavior, I continue with a comparison of selection outcomes and dynamics at the ward party level (for summary statistics, see the supplementary material).$^{68}$

Table 1 presents the results of Tobit models estimating the election of Muslim candidates. Tobit is appropriate here because the dependent variable is censored at zero. ${ }^{69}$ Results indicate that single-member districts have a negative effect on the share of councilors who are Muslim in a local authority, but this effect falls short of statistical significance. Both the overall size of the Muslim population and its concentration in wards within municipalities have positive impacts on the election of Muslim candidates to city halls. A 5 percent increase in a municipality's Muslim population (about one standard deviation) is associated

${ }^{65}$ Dancygier 2014.

${ }^{66}$ Dancygier 2014.

${ }^{67}$ The regressions do not include the extreme outlier Tower Hamlets, the borough with the highest Muslim population share (36.4 percent) and the lowest fractionalization index (.24). On average, 59.5 percent of the borough's elected candidates are Muslim, by far the highest in the sample. The effect of electoral rules stays insignificant when Tower Hamlets is included. The impact of the Muslim population's spatial concentration is not significant and smaller (but stays positive) while the effect of its regional fractionalization is more significant and larger.

${ }^{68}$ Dancygier 2014.

${ }^{69}$ When using OLS the main results remain: the effect of electoral rules is insignificant. The overall substantive results are very similar, with the exception that the effect of the fractionalization of the Muslim population which, though it remains negative, does not attain significance $(p=0.18)$. 
TABLE 1

The Election of Muslim Councillors in English Municipalitiesa ${ }^{a}$

\begin{tabular}{lcc}
\hline \hline SMD & -0.693 & $-1.768^{*}$ \\
\% Muslim Population & $(0.543)$ & $(0.895)$ \\
& $0.637^{* *}$ & $0.692^{* *}$ \\
Segregation & $(0.231)$ & $(0.239)$ \\
Fractionalization & $32.06^{* *}$ & $25.31^{*}$ \\
& $(10.52)$ & $(11.98)$ \\
\% Labour Vote & $-8.480+$ & $-8.645^{*}$ \\
& $(4.368)$ & $(4.335)$ \\
SMD $\times$ Segregation & -0.0223 & -0.0190 \\
& $(0.0445)$ & $(0.0439)$ \\
Year & & 6.529 \\
& & $(5.462)$ \\
Region Fixed Effects & $0.254^{*}$ & $0.258^{*}$ \\
Constant & $(0.113)$ & $(0.112)$ \\
Sigma & yes & yes \\
& $-504.5^{*}$ & $-512.3^{*}$ \\
N & $(227.1)$ & $(225.7)$ \\
Pseudo-R & $4.589^{* * *}$ & $4.586^{* * *}$ \\
N of Uncensored Observations & $(0.245)$ & $(0.247)$ \\
\hline
\end{tabular}

$+\mathrm{p}<0.1,{ }^{*} \mathrm{p}<0.05,{ }^{* * *} \mathrm{p}<0.01,{ }^{* * *} \mathrm{p}<0.001$

${ }^{\text {a }}$ The dependent variable is the percentage of elected candidates in a local authority who are Mus$\mathrm{lim}$. The unit of analysis is the local authority election. Tobit coefficients are displayed; robust standard errors, clustered on local authority, are in parentheses.

with a 3 percent rise in the share of councillors who are Muslim (about half a standard deviation).

To illustrate the importance of segregation, consider the boroughs of Kirklees and Oldham in the North. Both have similar-size Muslim populations of 10 and 11 percent, respectively, but Kirklees has an isolation index of .24 compared with Oldham's .39. This gap is associated in turn with an estimated difference in the share of Muslim councillors of approximately 4.8 percent. Indeed, the average percentage of elected Muslim candidates is 13.3 percent in Kirklees and 18 percent in Oldham. Oldham's Muslims are more residentially segregated, and they win a larger share of local seats as a result. Furthermore, as segregation rises, so does the impact of SMD in electing Muslim candidates, though this effect is barely significant and even then only when the isolation index falls below .12 (see Figure 1; the median isolation index is .08). Put differently, the negative effect of SMD indicates that SMD will reduce the share of Muslim councillors when there is no spatial segregation (the joint significance of the interaction term and SMD is 


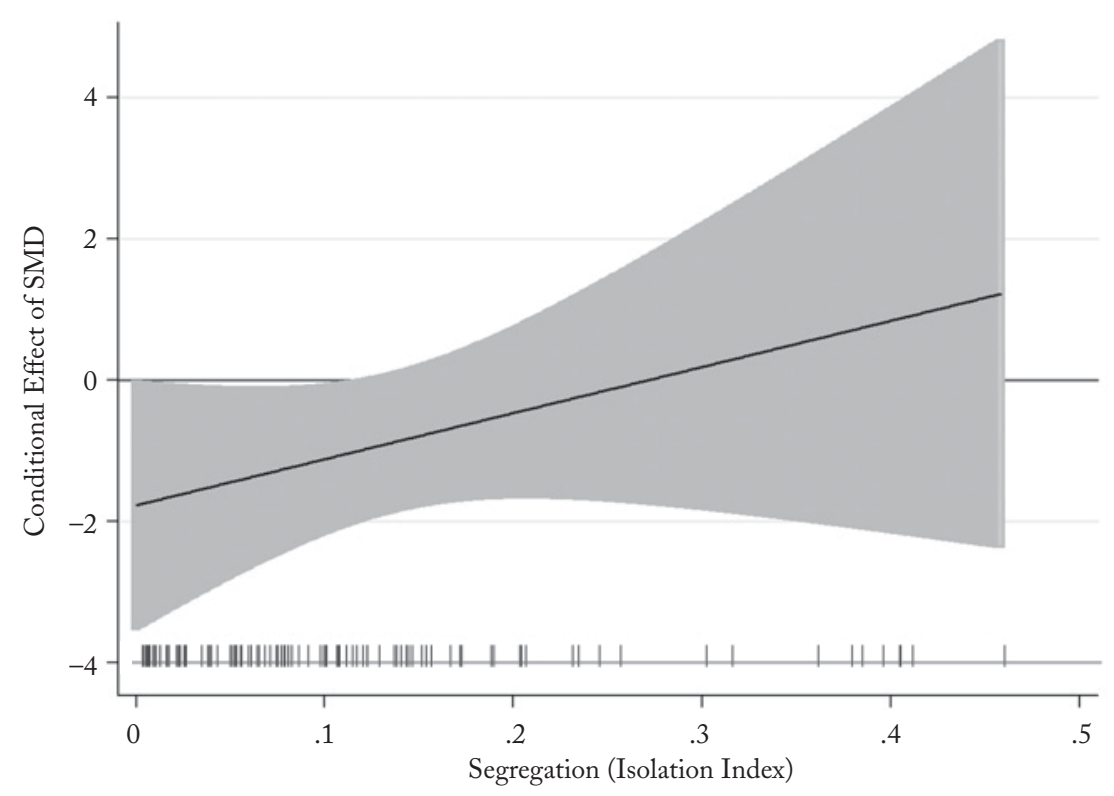

FIGURE 1

Conditional Effect of Electoral Rule on the Election of MusLim COUNCILlors ${ }^{\mathrm{a}}$

${ }^{\mathrm{a}}$ The dependent variable is the percentage of elected candidates in a local authority who are Muslim. The solid line traces the conditional effects; the shaded area covers the 95 percent confidence interval surrounding the effects. The rug plot (the vertical dashes along the $\mathrm{x}$-axis) depicts the values of the isolation index.

$p=0.107)$. Last, Muslim electorates appear to be more likely to elect coreligionists when they originate from a smaller number of countries. The Labour Party vote share is of little consequence.

These results are robust to the inclusion of a number of additional covariates. These include the shares of the Hindu, Sikh, and Jewish populations, as it could be that the presence of other religious groups influences elites' selection strategies, as well as the electorates' preference for Muslim candidates. I also include the local unemployment rate to test whether economically disadvantaged boroughs are less likely to elect minority candidates, as suggested by resource models of mobilization $^{70}$ and the size of the population (logged). None of these variables are significant, and their inclusion does not alter the main results (see the supplementary material for these results, as well as for models including additional controls). ${ }^{71}$

\footnotetext{
${ }^{70}$ Browning, Marshall, and Tabb 1984; Engstrom and McDonald 1986.

${ }^{71}$ Dancygier 2014. Further, it is not the case that the effect of SMD is conditional on the size of the Muslim population; the interaction of these two variables is not significant.
} 
What emerges from these findings is that the overall effect of SMD elections on the election of Muslim candidates is negative but not statistically significant (note that matching on the size of the Muslim population and on other covariates yields the same result). Consistent with previous research, we do observe that less segregated areas are less likely to elect Muslims in SMD contests, though the confidence interval surrounding this result is rather wide. The size of the Muslim population and its distribution are key for whether Muslims secure a seat on the city council.

Difference-in-difference regressions paint a similar picture. The DiD analysis below compares changes in election outcomes in the metropolitan boroughs (the treatment group) between 2004 and in 2006 with changes in election outcomes between 2002 and 2006 in London boroughs (the control group). ${ }^{72} \mathrm{I}$ also compare election outcomes in the 2004 MMD election with the aggregate share of Muslims elected in all three SMD elections (2006, 2007, and 2008) in metropolitan boroughs. ${ }^{73}$

Table 2 displays the electoral cycles included in the DiD analyses and the outcomes in Muslim descriptive representation across treatment and control groups, as well as the within- and across-group differences. In the treatment group, the switch to SMD in 2006 is accompanied by an increase in Muslim representation of 1.38 percentage points, but we observe a similar increase (1.29 points) in the control group, resulting

${ }^{72}$ One drawback of employing $\mathrm{DiD}$ with the data at hand is that metropolitan and London boroughs do not hold elections in identical years, though elections are very closely spaced. In studies that examine how electoral reforms affect black representation in the US, dates have also not coincided across groups, observations from the pre- and posttreatment periods have tended to be separated by more than ten years, and, importantly, assignment to groups may have been correlated with prior patterns of minority representation (for example, Grofman and Davidson 1994). There is, however, one potential concern that may arise - that elections in metropolitan boroughs were held after the onset of the Iraq War in 2003, which cost the Labour Party votes in the 2003 local elections (Hetherington 2003) and which was unpopular among Muslims (Curtice, Fisher, and Ford 2010). Note that the Labour Party vote share is included in the models. As a further check, I identified nine additional local authorities located throughout the country that use MMD elections; that held elections in 2003, following the invasion, and again in 2007; and that have a Muslim population of at least 2 percent (I chose this cutoff given the substantial amount of time it takes to enter candidates' names and to geocode the data). Results are very similar when using this alternative control group (models were run including all metropolitan boroughs and including only those whose Muslim population was also at least 2 percent). Finally, I examined the extent to which partisanship patterns actually shifted between the 2002 and 2006 elections. Though Labour's involvement in the Iraq war was an extremely salient issue among Muslims that caused some vote switching as well as the rise of the Respect Party, the overall distribution of candidate partisanship did not change much. In London and in the Metropolitan boroughs, the number of Muslim Labour candidates declined by 1.7 percent and 1.2 percent, respectively, while the number of Muslim Liberal Democrats rose slightly, by 3.8 and .1 percent, respectively. Further, despite the publicity surrounding Respect, note that only 5.9 percent of all Muslim candidates in the sample belong to the party. Last, the DiD results do not change when I control for the vote share attained by Respect.

${ }^{73}$ See also Bertrand, Duflo, and Mullainathan 2004, who recommend aggregating years as a way to address the problem of serial correlation. 
TABLE 2

Percent Elected Candidates Who Are Muslim in Treatment and Control Groups ${ }^{\mathrm{a}}$

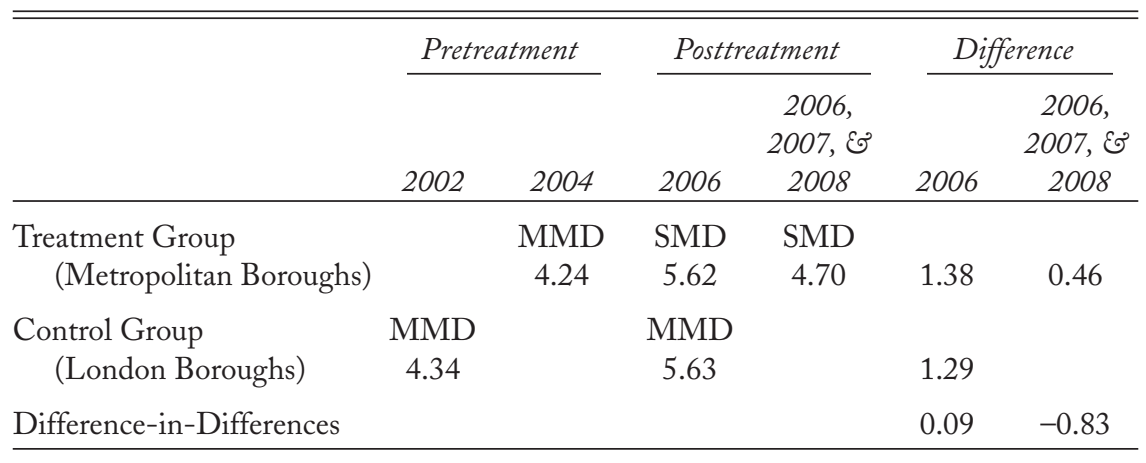

${ }^{a}$ Note that this table displays only the election years used in the DiD analysis. SMD elections included in the overall sample were also held in metropolitan boroughs in 2002 and 2003, but they cannot be used in the $\mathrm{DiD}$ analysis because ward boundaries were different from those used in elections taking place from 2004 onward.

in a small difference of .09. When comparing changes on the basis of results from 2006, 2007, and 2008, the difference in the change across groups is -.83 . Table 3 presents these results in a regression framework. The DiD estimator (the interaction term) is insignificant in both specifications. This result does not change when covariates are added (note that the effect of Segregation drops to $p=.11$ in one model and that Fractionalization is not consistently significant). Results are also robust to the inclusion of the battery of additional controls mentioned above (see the supplementary material). ${ }^{74}$

These results indicate that there is no significant relationship between the type of electoral rule and the share of Muslim councillors. This does not mean, however, that these rules are irrelevant in influencing processes of intraparty competition. As the previous discussion has indicated, intraparty dynamics at the selection stage can affect the fates of Muslim office seekers. Crossing the selection hurdle might be more difficult in winner-take-all SMD contests than in multimember contests. When a Muslim candidate does get selected and wins an SMD seat, however, he will be the sole winner in a given year and will not share this victory with other candidates who may be of different religions.

Table 4 illustrates these dynamics. It provides difference-of-means

${ }^{74}$ Dancygier 2014. 
TABLE 3

The Election of Muslim Councillors:

DiFFERENCE-IN-DiFFERENCE REgRESSIONS ${ }^{a}$

\begin{tabular}{|c|c|c|c|c|}
\hline \multirow[b]{2}{*}{ Treatment Group } & \multicolumn{2}{|c|}{ Comparison with 2006} & \multicolumn{2}{|c|}{$\begin{array}{c}\text { Comparison with } \\
\text { 2006, 2007, \& } 2008\end{array}$} \\
\hline & $\begin{array}{c}-0.102 \\
(1.198)\end{array}$ & $\begin{array}{l}1.011 \\
(0.868)\end{array}$ & $\begin{array}{l}-0.102 \\
(1.198)\end{array}$ & $\begin{array}{l}1.879^{*} \\
(0.856)\end{array}$ \\
\hline Posttreatment & $\begin{array}{c}1.291+ \\
(0.658)\end{array}$ & $\begin{array}{c}0.982 \\
(0.731)\end{array}$ & $\begin{array}{c}1.291+ \\
(0.658)\end{array}$ & $\begin{array}{c}0.940 \\
(0.727)\end{array}$ \\
\hline $\begin{array}{l}\text { Treatment Group } \times \\
\text { Posttreatment }\end{array}$ & $\begin{array}{c}0.0914 \\
(0.809)\end{array}$ & $\begin{array}{c}0.462 \\
(0.914)\end{array}$ & $\begin{array}{l}-0.830 \\
(0.699)\end{array}$ & $\begin{array}{l}-0.460 \\
(0.784)\end{array}$ \\
\hline \% Muslim Population & & $\begin{array}{l}0.731^{\text {***** }} \\
(0.152)\end{array}$ & & $\begin{array}{l}0.751^{\text {**** }} \\
(0.142)\end{array}$ \\
\hline Segregation & & $\begin{array}{l}13.57 \\
(8.440)\end{array}$ & & $\begin{array}{l}14.27+ \\
(7.377)\end{array}$ \\
\hline Fractionalization & & $\begin{array}{r}-8.387^{*} \\
(3.257)\end{array}$ & & $\begin{array}{l}-3.349 \\
(2.739)\end{array}$ \\
\hline \% Labour Vote & & $\begin{array}{l}-0.0512 \\
(0.0323)\end{array}$ & & $\begin{array}{c}-0.0582+ \\
(0.0301)\end{array}$ \\
\hline Constant & $\begin{array}{l}4.344 * * * \\
(0.693)\end{array}$ & $\begin{array}{r}6.273^{*} \\
(3.095)\end{array}$ & $\begin{array}{l}4.344^{* * *} \\
(0.693)\end{array}$ & $\begin{array}{c}2.074 \\
(2.660)\end{array}$ \\
\hline $\mathrm{N}$ & 134 & 134 & 134 & 134 \\
\hline $\mathrm{R}^{2}$ & 0.013 & 0.769 & 0.010 & 0.804 \\
\hline
\end{tabular}

$+\mathrm{p}<0.10,{ }^{*} \mathrm{p}<0.05,{ }^{* * *} \mathrm{p}<0.01,{ }^{* * * *} \mathrm{p}<0.001$

${ }^{a}$ The dependent variable is the percentage of elected candidates in a local authority who are Mus$\mathrm{lim}$. The unit of analysis is the local authority election. OLs coefficients are displayed; robust standard errors, clustered on local authority, are in parentheses.

tests for metropolitan boroughs that switched electoral rules and where demographic and other variables are therefore held constant. The observations are restricted to the three major parties: Labour, Conservatives, and Liberal Democrats. ${ }^{75}$

Note that by comparing selection outcomes in the same locations in closely spaced election years, a host of slow-changing demographic, occupational, and socioeconomic candidate-level variables that may influence the supply of available minority office seekers ${ }^{76}$ are held relatively constant. We can therefore be more confident that the ways in which parties respond to changes in electoral rules (rather than differences in the pool of available candidates) account for the patterns we observe.

Given the thousands of ward parties, the overall share of Muslim

75 The results are substantively identical when all parties are included. I focus on the major parties to exclude independent candidates and smaller parties that may compete only if a candidate steps forward in the first place.

${ }^{76}$ Ali and O'Cinneide 2002; Norris, Geddes, and Lovenduski 1992. 
TABLE 4

Muslim Candidates, by Electoral Rule

\begin{tabular}{|c|c|c|c|}
\hline & \multicolumn{3}{|c|}{$\begin{array}{l}\text { Metropolitan Boroughs Only } \\
\text { (Postboundary Changes) }\end{array}$} \\
\hline & $S M D$ & $\begin{array}{c}M M D \\
\text { (3 Open } \\
\text { Seats) }\end{array}$ & $\begin{array}{l}\text { Significance } \\
\text { (two-tailed) }\end{array}$ \\
\hline \% Winners in Party Who Are Muslim & 1.78 & 1.66 & $\begin{array}{l}\mathrm{t}=0.40 \\
\mathrm{p}=0.689\end{array}$ \\
\hline \% Parties That Run a Muslim Candidate & 6.36 & 11.22 & $\begin{array}{l}\mathrm{t}=-7.61 \\
\mathrm{p}=0.000\end{array}$ \\
\hline $\mathrm{N}$ & 6,745 & 2,290 & \\
\hline $\begin{array}{l}\text { \% Muslim Winners in Party If Party Runs } \\
\text { a Muslim Candidate }\end{array}$ & 27.97 & 14.79 & $\begin{array}{l}\mathrm{t}=4.34 \\
\mathrm{p}=0.000\end{array}$ \\
\hline $\mathrm{N}$ & 429 & 257 & \\
\hline $\begin{array}{l}\text { \% Muslim Candidates Overall: } \\
3 \text { SMD vs. } 1 \text { MMD election }\end{array}$ & 6.36 & 6.38 & $\begin{array}{l}\mathrm{t}=-.0559 \\
\mathrm{p}=0.955\end{array}$ \\
\hline $\mathrm{N}$ & 6,745 & 6,140 & \\
\hline
\end{tabular}

winners at the party level is quite low. In single-member elections, the share of winners who are Muslim is 1.78 percent compared with 1.66 percent in multimember races $(p=0.689)$; in line with the foregoing analysis, there is no significant difference across electoral rules. Differences do emerge at the selection stage: in any given election, securing a spot on the ticket is more difficult for a potential Muslim candidate in SMD contests. In metropolitan boroughs, 11 percent of ward parties run Muslim candidates when three seats are available in an election, but this share drops to only 6 percent when potential candidates vie for only one open seat. The more seats are available, the more likely it is that a Muslim candidate will be on the ticket. Note, however, that this outcome may occur absent discriminatory behavior of parties. If seats were allocated randomly, we would expect a similar result: the chance of selection rises for any given candidate as the number of seats increases. Is it the case, then, that Muslims are equally likely to be selected in three single-member races as they are in one three-member race? Examining the pool of candidates, I find that shares are indeed identical across systems (6.4 percent in each; $p=0.955)$. One might be concerned that this result is due to the fact that parties who won in 2004 reselect the same incumbent candidates in subsequent elections. 
However, the difference in the share of Muslim candidates across electoral rules among parties whose candidates did not win in 2004 is small (.59 points) and not statistically significant $(p=.288)$. These results suggest that it is more difficult for a Muslim office seeker to cross the selection hurdle in a single-member contest than in a multimember election. On average, however, parties do balance the slate across elections in SMD contests (in 40 percent of ward parties that run a Muslim candidate in MMD elections in 2004 the number of Muslim candidates is the same in the MMD election as it is in three consecutive SMD elections).

I next examine whether electoral rules matter in influencing the type of seat that is being contested by Muslim candidates. As mentioned above, parties may be more willing to place Muslims on the ballot in seats the party has less chance of winning. Though this kind of discrimination may also occur in MMD races, it may be relatively more common in SMD contests. When party leaders are forced to choose between candidates in any given election, they may be more likely to allocate the only slot they have to a non-Muslim candidate, due to their own reservations about nominating a Muslim or because of prejudice they impute to the local electorate. This resistance will decline, however, as the share of the Muslim population rises. In wards where a significant share of the electorate is Muslim, non-Muslim elites may hope to garner the support of a high-turnout Muslim electorate, while Muslim residents themselves will be able to influence the selection process as party members without having to rely on the goodwill of local elites to surrender desirable seats to minority candidates.

To test these propositions, I investigate the determinants of selection at the ward party level. I first test whether selection becomes less likely in SMD seats as seats become safer. The dependent variable is dichotomous and measures whether or not a party runs a Muslim candidate. As before, I include the share of the Muslim population, albeit at the ward level. Previous Vote Margin denotes the (negative) difference in vote shares between a party that lost and the winning party in the preceding election or, in the case of a party that won the previous election, the (positive) difference between its vote share and the runner up (in MMD elections, the vote share of a party's top vote getter is used; results are very similar using average party vote shares). As Previous Vote Margin rises, the safer and more desirable the ticket. ${ }^{77} \mathrm{I}$ also add

\footnotetext{
${ }^{77}$ We might be concerned about endogeneity in the face of candidate renomination. The results presented below are robust to controlling for whether or not the same candidate ran in the previous election and to restricting the sample to parties whose candidates did not compete in the previous election.
} 
party and regional dummies. Segregation is excluded because this variable can be measured only at the borough level (using ward-level population shares), and, given ward-level elections, it is at the borough level that this variable is substantively meaningful. Finally, ward-level fractionalization along national origins could not be included in the regressions using metropolitan boroughs, as this variable is not available for local authorities whose wards underwent boundary changes after the 2001 census.

Table 5 (column 1) shows that as seats become safer, parties are less likely to run Muslim candidates in SMD contests. When one seat is up for election, the less attractive the seat, the more likely it is to feature a Muslim on the ticket. Yet the top panel in Figure 2 illustrates that this effect in SMD is conditional on the size of a ward's Muslim population. ${ }^{78}$ Once Muslim residents constitute approximately 20 percent of the population, selection becomes more likely as vote margins increase and parties become popular. When the local Muslim population reaches 40 percent, a one standard deviation increase in a party's vote margin is associated with a seven-point rise in the probability of selecting a Muslim candidate (about one-third of a standard deviation). In these wards, Muslims' electoral leverage and involvement in party politics allow them to run in competitive seats. This is because non-Muslim elites recognize the value of running candidates who may appeal to a sizable, high-turnout religious minority electorate and they may be able to afford the vote loss that a Muslim candidate could trigger. Additionally, as the position of traditional gatekeepers erodes, Muslim party members are themselves involved in selecting coethnics to represent their ward.

These findings match up nicely with local case studies. In Birmingham in the 1990s, for instance, the Sparkbrook ward Labour branch counted six hundred Pakistani members out of a total of eight hundred, while 95 percent of the Labour Party membership in Handsworth ward was of Pakistani origin (in 1991, 31 and 17 percent of residents in Sparkbrook and Handsworth, respectively, were of Pakistani origin; religion was not measured until the 2001 census). Pakistani-origin Muslims have therefore controlled ward politics, including SMD selection outcomes, leading some non-Muslim party members and voters to feel marginalized and to make charges of corrupt recruitment processes. ${ }^{79}$

\footnotetext{
${ }^{78}$ The panel is based on the second column in Table 5; it shows the effect of a one standard deviation increase in the Previous Vote Margin at different levels of the size of the Muslim population.

${ }^{79}$ Garbaye 2005.
} 
TABLE 5

The Selection of Muslim Candidates by Local Parties, by Electoral Rule ${ }^{a}$

\begin{tabular}{lcccc}
\hline \hline & \multicolumn{2}{c}{$S M D$} & \multicolumn{2}{c}{$M M D$} \\
\hline \% Muslim Population & $0.0606^{* * * *}$ & $0.0672^{* * *}$ & $0.0810^{* * *}$ & $0.0829^{* * *}$ \\
& $(0.00267)$ & $(0.00279)$ & $(0.00586)$ & $(0.00681)$ \\
Previous Vote Margin & $-0.436^{* * *}$ & $-0.816^{* * * *}$ & -0.0548 & -0.196 \\
& $(0.104)$ & $(0.115)$ & $(0.104)$ & $(0.204)$ \\
Fractionalization & & -0.282 & -0.270 \\
& & & $(0.599)$ & $(0.600)$ \\
Previous Vote Margin $\times$ & & $0.0408^{* * *}$ & & 0.0166 \\
\% Muslim Population & & $(0.00919)$ & & $(0.0215)$ \\
Liberal Democrats & $-0.170^{*}$ & $-0.143+$ & $-0.163^{*}$ & $-0.146+$ \\
& $(0.0705)$ & $(0.0734)$ & $(0.0780)$ & $(0.0806)$ \\
Conservatives & $-0.437^{* * * *}$ & $-0.370^{* * *}$ & $-0.394^{* * *}$ & $-0.368^{* * *}$ \\
& $(0.0851)$ & $(0.0844)$ & $(0.0707)$ & $(0.0775)$ \\
Year & $0.0535^{* * * *}$ & $0.0540^{* * * *}$ & $0.0494^{* * *}$ & $0.0491^{* * *}$ \\
& $(0.0155)$ & $(0.0155)$ & $(0.0119)$ & $(0.0119)$ \\
Region Fixed Effects & yes & yes & no & no \\
Constant & $-109.3^{* * *}$ & $-110.4^{* * *}$ & $-100.5^{* * *}$ & $-99.82^{* * *}$ \\
& $(31.07)$ & $(31.10)$ & $(23.98)$ & $(23.98)$ \\
N & 8,841 & 8,841 & 3,380 & 3,380 \\
Pseudo-R ${ }^{2}$ & 0.354 & 0.362 & 0.144 & 0.144 \\
\hline
\end{tabular}

$+\mathrm{p}<0.10,{ }^{*} \mathrm{p}<0.05,{ }^{* *} \mathrm{p}<0.01,{ }^{* * *} \mathrm{p}<0.001$

a The dichotomous dependent variable is whether or not a party runs a Muslim candidate, with parties that run a Muslim candidate coded one and zero otherwise. The unit of analysis is the ward party election. Probit coefficients are displayed; robust standard errors, clustered on the ward, are in parentheses.

Returning to the present data, in MMD elections ${ }^{80}$ the competitiveness of the seat plays less of a role in selection outcomes. Though we do observe that the effect of Previous Vote Margin responds to the size of the Muslim population, the size of this effect is small and the confidence intervals are quite wide. ${ }^{81} \mathrm{~A}$ party's prior vote margin has no significant impact on whether or not parties decide to opt for Muslim candidates (see Table 5, columns 3 and 4, and Figure 2, bottom

\footnotetext{
${ }^{80}$ Because the analyses make use of results from the previous election, I cannot include 2004 MMD elections in metropolitan boroughs, since the preceding elections were held using different ward boundaries. To rule out the possibility that the effects just presented are attributable to unobservable characteristics of London boroughs rather than driven by electoral rules, I identified nine additional local authorities that also conduct three-member elections in several hundred wards (see fn 72). Here, as in London, parties' previous vote margins do not influence whether Muslim candidates get a spot on the ticket.

${ }^{81}$ When pooling SMD and MMD races, we also observe a statistically significant negative effect when interacting SMD with Previous Vote Margin ( $\mathrm{p}=0.004)$.
} 

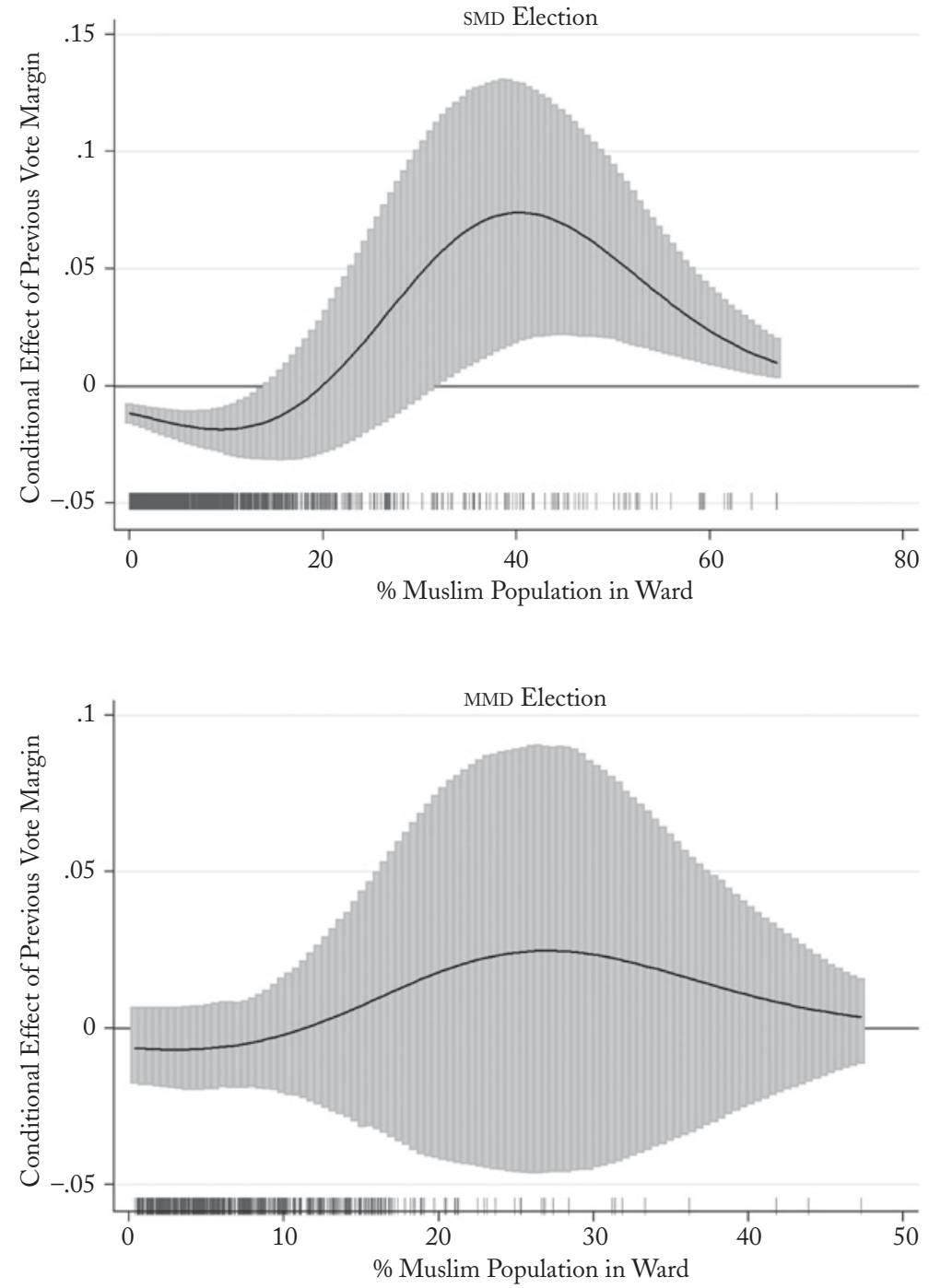

FIGURE 2

\section{Conditional Effects of Parties' Previous Vote Margins on the Selection of Muslim Candidates, by Electoral Rule ${ }^{a}$}

${ }^{\text {a }}$ The dependent variable is whether or not a ward party runs a Muslim candidate. The solid lines trace the conditional effects of a one standard deviation change of Previous Vote Margin; the shaded areas cover the 95 percent confidence intervals surrounding the effects. The rug plots (the vertical dashes along the $\mathrm{x}$-axes) depict the values of the percent Muslim population in the ward. To simulate these effects in SMD elections, the effect is estimated for the Labour Party in 2006 in the Yorkshire and the Humber Region. In MMD elections, the effect is estimated for the Labour Party in 2006 in London in a ward with a mean fractionalization index. 
panel). ${ }^{82}$ Note that results are similar and larger in magnitude when using a dummy measuring whether the previous vote margin is above or below the median (see the supplementary material). ${ }^{83}$ In both electoral systems, the size of the Muslim population is crucial in securing selection. For example, a one standard deviation increase in the Muslim population from its mean (from 4.2 to 13.7 percent) raises the probability of observing Muslim selection by 10 points, from 5 to 15 percent; a two standard deviation increase is associated with a rise of 26 points (based on column 1 in Table 5).

In short, the tendency to place Muslim candidates on tickets they are unlikely to win is mainly a feature of SMD contests. Once again, however, Muslims' electoral strength conditions this effect and critically shapes Muslims' entry into local politics.

\section{Discussion And Conclusion}

What, then, is the role of electoral institutions in explaining the election and selection of Muslims in England? On the whole, the evidence presented in this article indicates that single-member and multimember elections are not associated with different rates of Muslim descriptive representation. However, these rules do matter at the selection stage in influencing Muslims' access to local electoral politics. In any given election Muslims have a higher chance of getting on the ballot in multimember contests than they do in single-seat races. When only one seat is up for election, however, parties tend to balance the slate across multiple single-seat elections resulting in the same share of Muslim candidates across systems. Moreover, when only one seat is in play, the selection of Muslims becomes more likely as seats become less safe and therefore less desirable.

While these results demonstrate that electoral institutions matter in the selection of Muslim candidates, the findings also indicate that institutional effects are largely conditional on the electoral clout of the local Muslim population. Muslim candidates are more likely to compete in winning single-member seats once they are a sufficiently large voting bloc. Muslim office seekers thus benefit from single-member

\footnotetext{
${ }^{82}$ These results also hold at the candidate level. Because of the difficulty in constructing the Previous Vote Margin across all MMD candidates (that is, for a given party, each candidate will be assigned the same previous winning margin, as this is a party-level variable), I do not report these results here. Nevertheless, I ran regressions at the candidate level for MMD wards and the results are very similar: the Previous Vote Margin, including its interaction with the size of the Muslim population, is not significant in MMD races at the candidate level.

${ }^{83}$ Dancygier 2014.
} 
elections when they are backed by a sizable coethnic electorate whose representatives act as both voters and party selectors. Electoral institutions aside, the findings demonstrate that both the size and the spatial concentration of the Muslim population are vital in getting coethnics selected and elected.

Does the centrality of demographics mean that we observe what Horowitz has termed "census elections," where ethnicity becomes the sole guiding principle among party selectors and voters? ${ }^{84}$ Is demography electoral destiny in the case of an electorally mobilized minority group whose members tend to show up on election day? On the one hand, the data presented here and the qualitative accounts cited above seem to lend support to this interpretation: large local Muslim populations are associated with election, selection, and with more favorable seat placement. On the other hand, it does not appear to be the case that the religious background of candidates is the key feature that drives Muslim and non-Muslim decisions at the polls. Muslim candidates rarely compete in wards where few Muslims reside, but when they do they sometimes win. ${ }^{85}$ Moreover, candidates who run on the same party ticket in the same multimember ward election, but who differ in their religious backgrounds, tend to obtain similar vote shares. ${ }^{86}$ These aggregate results are consistent with voters-Muslim and nonMuslim alike-who are not polarized along religious lines. ${ }^{87}$

When it comes to entering local party politics at the candidate level, however, candidates' ethnoreligious background seems to matter a great deal more. In this case, electoral institutions mediate the significance of religion to a certain degree, but the mobilizational capacity of Muslims and especially their ability to enter ward parties and to help select favored candidates in areas of Muslim electoral strength prove most important. One implication of these findings is that parties-more so than electoral rules and voters - present both institutional barriers and opportunities. Examining the attitudes and behaviors of party selectorates and how these might vary across contexts would thus be a natural extension of the present research. ${ }^{88}$

How do the present findings speak to the political inclusion of Muslims and ethnic minorities more generally and in other contexts?

\footnotetext{
${ }^{84}$ Ferree 2011; Horowitz 1985.

${ }^{85}$ In the sample, 1.6 percent of candidates in wards with Muslim populations below 5 percent are Muslim; 12 percent of these win.

${ }^{86} \mathrm{On}$ average, Muslims attain slightly fewer votes than do their non-Muslim copartisans, and this proportion tends to rise and fall with the size of the Muslim population (Dancygier 2013).

${ }^{87}$ See also Saggar 1998.

${ }^{88}$ Cf. Bloemraad 2013; Norris, Geddes, and Lovenduski 1992. I address parts of this question in Dancygier 2013, focusing on the Labour Party.
} 
Though local electoral rules vary widely across European countries, we can observe some similarities in the ways in which institutions that bestow power on party elites can also place a premium on the mobilization of ethnic networks and thereby help immigrant minorities circumvent traditional gatekeepers. In Denmark, Belgium, the Netherlands, and Norway, for instance, where at-large elections are held according to proportional representation (PR), voters may cast preference votes for specific candidates. Though multimember PR elections have been said to increase the odds of selection as compared with single-member contests, elites often place minority candidates near the bottom of party lists, making election victory elusive. Yet preferential voting has been shown to boost the position of immigrant-origin candidates who may be particularly attractive to the coethnic electorate, sometimes facilitating their election to city councils. In cities with large immigrant-origin populations, ethnically based mobilization - and not necessarily acceptance by party elites and native voters-has thus brought about representation. ${ }^{89}$

These findings complement the present results in that it is those minority groups that can successfully mobilize coethnics who are in a position to bypass existing elites and take advantage of electoral rules. Future work should examine the extent to which institutions promote intraethnic mobilization rather than interethnic linkages within parties and, further, how these different pathways of electoral inclusion structure minorities' social and political incorporation more broadly defined.

\section{Supplementary Material}

Supplementary material for this article can be found at http://dx.doi.org/10.1017 /S0043887114000021.

\section{REFERENCES}

Adida, Claire, David Laitin, and Marie-Anne Valfort. 2010. "Identifying Barriers to Muslim Integration in France." Proceedings of the National Academy of Sciences 107, no. 52: 22384-90.

Ali, Rushanara, and O'Cinneide Colm. 2002. Our House? Race and Representation in British Politics. London, UK: Institute for Public Policy Research.

Anwar, Muhammad. 2001. "The Participation of Ethnic Minorities in British Politics." Journal of Ethnic and Migration Studies 27, no. 3: 533-49.

${ }^{89}$ Bird, Saalfeld, and Wüst 2011; Bergh and Bjørklund 2011; Togeby 2008. 
Bergh, Johannes, and Tor Bjørklund. 2011. "The Revival of Group Voting: Explaining the Voting Preferences of Immigrants in Norway." Political Studies 59, no. 2: 308-27.

Bertrand, Marianne, Esther Duflo, and Sendhil Mullainathan. 2004. "How Much Should We Trust Differences-in-Differences Estimates?" Quarterly Journal of Economics 119, no. 1: 249-75.

Bird, Karen, Thomas Saalfeld, and Andreas Wüst, eds. 2011. The Political Representation of Immigrants and Minorities: Voters, Parties and Parliaments in Liberal Democracies. New York, N.Y.: Routledge.

Bleich, Erik, and Rahsaan Maxwell. 2012. "Assessing Islamophobia in Britain: Where Do Muslims Really Stand?" In Marc Helbling, ed., Islamophobia in the West. London, UK: Routledge.

Bloemraad, Irene. 2006. Becoming a Citizen: Incorporating Immigrants and Refugees in the United States and Canada. Berkeley, Calif.: University of California Press.

—. 2013. "Accessing the Corridors of Power: Enduring Puzzles and Future Pathways to Understanding Cross-national Differences in Minority Representation." West European Politics 36, no. 3: 652-70.

Brouard, Sylvain, and Vincent Tiberj. 2005. Français comme les autres? Enquête sur les citoyens d'origine maghrébine, africaine et turque. Paris, France: Sciences Po.

2011. "Yes They Can: An Experimental Approach to the Eligibility of Ethnic Minority Candidates in France.” In Karen Bird, Thomas Saalfeld, and Andreas Wüst, eds., The Political Representation of Immigrants and Minorities: Voters, Parties, and Parliaments in Liberal Democracies. New York, N.Y.: Routledge.

Browning, Rufus P., Dale R. Marshall, and David H. Tabb. 1984. Protest Is Not Enough: The Struggle of Blacks and Hispanics for Equality and Urban Politics. Berkeley, Calif.: University of California Press.

Bullock, Charles, and Ronald Gaddie. 1993. "Changing from Multimember to Single-Member Districts: Partisan, Racial, and Gender Consequences.” State and Local Government Review 25, no. 3: 155-63.

Bullock, Will. 2010. "Disentangling the Effects of Multi-Member Districts in Electing Women to State Legislatures.” Manuscript, Princeton University.

Cameron, Charles, David Epstein, and Sharyn O'Halloran. 1996. "Do MajorityMinority Districts Maximize Substantive Black Representation in Congress?" American Political Science Review 90, no. 4: 794-812.

Chandra, Kanchan. 2004. Why Ethnic Parties Succeed: Patronage and Ethnic Headcounts in India. Cambridge, UK: Cambridge University Press.

Chattopadhyay, Raghabendra, and Esther Duflo. 2004. "Women as Policy Makers: Evidence from a Randomized Policy Experiment in India." Econometrica 72, no. 5: 1409-43.

Chauchard, Simon. Forthcoming. "Can Descriptive Representation Change Beliefs about a Stigmatized Group? Evidence from Rural Rajasthan.” American Political Science Review.

Copus, Colin. 2004. Party Politics and Local Government. Manchester, UK: Manchester University Press.

Curtice, John, Stephen Fisher, and Robert Ford. 2010. "Appendix 2: An Analysis of the Results." In D. Kavanagh and P. Cowley, eds., The British General Election of 2010. New York, N.Y.: Palgrave Macmillan. 
Dancygier, Rafaela M. 2010. Immigration and Conflict in Europe. New York, N.Y.: Cambridge University Press.

- 2013. "The Left and Minority Representation: The Labour Party, Muslim Candidates, and Inclusion Tradeoffs." Comparative Politics 46, no. 1: 1-21.

- 2014. Supplementary material. At http://dx.doi.org/10.1017/S004388 7114000021.

Darcy, R., Susan Welch, and Janet Clarke. 1985. "Women Candidates in Singleand Multi-Member Districts: American State Legislative Races." Social Science Quarterly 66, no. 4: 945-53.

Dunning, Thad, and Janhavi Nilekani. 2013. "Ethnic Quotas and Political Mobilization: Caste, Parties, and Distribution in Indian Village Councils." American Political Science Review 107, no. 1: 35-56.

Eade, John. 1989. The Politics of Community. Aldershot, UK: Avebury.

Electoral Commission. 2002. "Periodic and Future Electoral Reviews: Guidance and Procedural Advice.” London, UK: Electoral Commission.

Engstrom, Richard L., and Michael D. McDonald. 1986. "The Effect of AtLarge versus District Elections on Racial Representation in U.S. Municipalities." In B. Grofman and A. Lijphart, eds., Electoral Laws and Their Political Consequences. New York, N.Y.: Agathon Press.

Ferree, Karen. 2011. Framing the Race in South Africa: The Political Origins of Racial Census Elections. New York, N.Y.: Cambridge University Press.

Fieldhouse, Edward, and David Cutts. 2008. "Mobilisation or Marginalisation? Neighbourhood Effects on Muslim Electoral Registration in Britain in 2001." Political Studies 56, no. 2: 333-54.

Ford, Robert. 2011. "Acceptable and Unacceptable Immigrants: How Opposition to Immigration in Britain Is Affected by Migrants' Region of Origin." Journal of Ethnic and Migration Studies 37, no. 7: 1017-37.

Garbaye, Romain. 2005. Getting into Local Power: The Politics of Ethnic Minorities in British and French Cities. Oxford, UK: Blackwell Publishing.

Geddes, Andrew. 1998. "Inequality, Political Opportunity, and Ethnic Minority Parliamentary Candidacy." In Shamit Saggar, ed., Race and British Electoral Politics. London, UK: UCL Press.

Geisser, Vincent. 1997. Ethnicité Républicaine. Paris, France: Presses de Sciences Po.

Givens, Terri, and Rahsaan Maxwell, eds. 2012. Immigrant Politics: Race and Representation in Western Europe. Boulder, Colo.: Lynne Rienner.

Grofman, Bernard. 1982. "The Effect of Ward vs. At-large Elections on Minority Representation, Part II, A Review and Critique of Twenty-three Recent Empirical Studies.” Manuscript.

Grofman, Bernard, and Chandler Davidson. 1994. "The Effect of Municipal Election Structure on Black Representation in Eight Southern States." In C. Davidson and B. Grofman, eds., Quiet Revolution in the South: The Impact of the Voting Rights Act 1965-1990. Princeton, N.J.: Princeton University Press.

Habyarimana, James, Macartan Humphreys, Daniel N. Posner, and Jeremy M. Weinstein. 2009. Coethnicity: Diversity and the Dilemmas of Collective Action. New York, N.Y.: Russell Sage Foundation.

Hajnal, Zoltan L. 2007. Changing White Attitudes toward Black Political Leadership. New York, N.Y.: Cambridge University Press.

Heath, Anthony, Stephen D. Fisher, David Sanders, and Maria Sobolewska. 
2011. "Ethnic Heterogeneity in the Social Bases of Voting in the 2010 General Election." Journal of Elections, Public Opinion, and Parties 21, no. 2: 255-77.

Helbling, Marc, ed. 2012. Islamophobia in the West: Measuring and Explaining Individual Attitudes. London, UK: Routledge.

Hetherington, Peter. 2003. "English Local Elections: Labour Hit by Tax Rises and 'Baghdad Backlash." Guardian. May 3.

Hochschild, Jennifer, and John Mollenkopf, eds. 2009. Bringing Outsiders In: Transatlantic Perspectives on Immigrant Political Incorporation. Ithaca, N.Y.: Cornell University Press.

Horowitz, Donald L. 1985. Ethnic Groups in Conflict. Berkeley, Calif.: University of California Press.

Jacobs, Dirk, Marco Martiniello, and Andrea Rea. 2002. "Changing Patterns of Political Participation of Citizens of Immigrant Origin in the Brussels Capital Region: The October 2000 Elections.” Journal of International Migration and Integration 3, no. 2: 201-21.

Johnston, Ron, Michael Poulsen, and James Forrest. 2005. "On the Measurement and Meaning of Residential Segregation: A Response to Simpson." Urban Studies 42, no. 7: 1221-27.

Joppke, Christian. 2009. "Limits of Integration Policy: Britain and Her Muslims." Journal of Ethnic and Migration Studies 35, no. 3: 453-72.

King, James D. 2002. "Single-Member Districts and the Representation of Women in American State Legislatures: The Effects of Electoral System Change." State Politics and Policy Quarterly 2, no. 2: 161-75.

Kittilson, Miki Caul. 2006. Challenging Parties, Challenging Parliaments: Women and Elected Office in Western Europe. Columbus, Ohio: Ohio State University Press.

Klausen, Jytte. 2005. The Islamic Challenge: Politics and Religion in Europe. Oxford, UK: Oxford University Press.

Labour Party. 2008. The Labour Party Rule Book 2008. London, UK: Labour Party.

Lakha, F., Dermot R. Gorman, and Pablo Mateos. 2011. "Name Analysis to Classify Populations by Ethnicity in Public Health: Validation of Onomap in Scotland." Public Health 125, no. 10: 688-96.

Laurence, Jonathan. 2012. The Emancipation of Europe's Muslims. Princeton, N.J.: Princeton University Press.

Lawless, Jennifer, and Richard Fox. 2010. It Still Takes a Candidate: Why Women Don't Run for Office. New York, N.Y.: Cambridge University Press.

Leach, Steve. 2006. The Changing Role of Local Politics in Britain. Bristol, UK: Policy Press.

Le Lohé, Michel. 1998. "Ethnic Minority Participation and Representation in the British Electoral System.” In Shamit Saggar, ed., Race and British Electoral Politics. London, UK: UCL Press.

Lopez, David, and Yen Espiritu. 1990. "Panethnicity in the United States: A Theoretical Framework." Ethnic and Racial Studies 13, no. 2: 198-224.

Lovenduski, Joni, and Pippa Norris, eds. 1993. Gender and Party Politics. London, UK: Sage Publications.

Mansbridge, Jane. 1999. "Should Blacks Represent Blacks and Women Represent Women? A Contingent 'Yes.”' Journal of Politics 61, no. 3: 628-57.

Marschall, Melissa J., Anirudh V. S. Ruhil, and Paru R. Shah. 2010. “The New 
Racial Calculus: Electoral Institutions and Black Representation in Local Legislatures." American Journal of Political Science 54, no. 1: 107-24.

Massey, Douglas S., and Nancy A. Denton. 1988. "The Dimensions of Residential Segregation.” Social Forces 67, no. 2: 281-315.

Mateos, Pablo. 2013. Names, Ethnicity and Populations. Heidelberg, Germany: Springer.

Matland, Richard E. 1993. "Institutional Variables Affecting Female Representation in National Legislatures: The Case of Norway." Journal of Politics 55, no. 3: 737-55.

Matland, Richard E., and Deborah Dwight Brown. 1992. "District Magnitude's Effect on Female Representation in U.S. Legislatures." Legislative Studies Quarterly 27, no. 4: 469-92.

Maxwell, Rahsaan. 2010. "Trust in Government among British Muslims: The Importance of Migration Status.” Political Behavior 32, no. 1: 89-109.

- 2012. Ethnic Minority Migrants in Britain and France: Integration Tradeoffs. New York, N.Y.: Cambridge University Press.

Modood, Tariq. 2003. "Muslims and the Politics of Difference." Political Quarterly 74, Supplement s1: 100-15.

Murray, Rainbow. 2008. "The Power of Sex and Incumbency: A Longitudinal Study of Electoral Performance in France." Party Politics 14, no. 5: 539-54.

Murshid, Kumar. 2004. "Seeking a Voice for London Muslims." Q-News, no. 354: 26-27.

Norris, Pippa. 1993. "Conclusions: Comparing Legislative Recruitment." In Pippa Norris and Joni Lovenduski, eds., Gender and Party Politics. London, UK: Sage.

- 2004. Electoral Engineering: Voting Rules and Political Behavior. New York, N.Y.: Cambridge University Press.

Norris, Pippa, Andrew Geddes, and Joni Lovenduski. 1992. "Race and Parliamentary Representation.” In P. Norris, I. Crewe, D. Denver, and D. Broughton, eds., British Elections and Parties Yearbook 1992. New York, N.Y.: Harvester Wheatsheaf.

Norris, Pippa, and Joni Lovenduski. 1995. Political Recruitment: Gender, Race and Class in the British Parliament. New York, N.Y.: Cambridge University Press.

Phillips, Anne. 1995. The Politics of Presence. Oxford, UK: Oxford University Press.

Pitkin, Hanna. 1967. The Concept of Representation. Berkeley, Calif.: University of California Press.

Posner, Daniel P. 2005. Institutions and Ethnic Politics in Africa. New York, N.Y.: Cambridge University Press.

Purdam, Kingsley. 1998. "The Impact of Democracy on Identity: Muslim Councillors and Their Experiences of Local Politics in Britain.” Ph.D. diss., Department of Government, University of Manchester, UK.

Rallings, Colin, Michael Thrasher, Galina Borisyuk, and Mary Shears. 2010. "Parties, Recruitment and Modernisation: Evidence from Local Election Candidates." Local Government Studies 36, no. 3: 361-79.

Ruedin, Didier. 2009. "Ethnic Group Representation in a Cross-National Comparison." Journal of Legislative Studies 15, no. 4: 335-54.

Rule, Wilma. 1987. "Electoral Systems, Contextual Factors and Women's Op- 
portunity for Election to Parliament in Twenty-three Democracies." Western Political Quarterly 40, no. 3: 477-98.

Saggar, Shamit. 2009. Pariah Politics: Understanding Western Radical Islamism and What Should Be Done. Oxford, UK: Oxford University Press.

Saggar, Shamit, ed. 1998. Race and British Electoral Politics. London, UK: UCL Press.

Sinno, Abdulkader, and Eren Tatari. 2009. "Muslims in UK Institutions: Effective Representation or Tokenism?" In Abdulkader Sinno, ed., Muslims in Western Politics. Bloomington, Ind.: Indiana University Press.

Solomos, John, and Les Back. 1995. Race, Politics, and Social Change. London, UK: Routledge.

Tatari, Eren. 2010. "The Contingency Theory of Descriptive Representation: Muslims in British Local Government." Ph.D. diss., Indiana University, Bloomington.

Togeby, Lise. 2008. "The Political Representation of Ethnic Minorities: Denmark as a Deviant Case." Party Politics 14, no. 3: 325-43.

Trounstine, Jessica, and Melody E. Valdini. 2008. "The Context Matters: The Effects of Single-Member vs. At-Large Districts on City Council Diversity." American Journal of Political Science 52, no. 3: 554-69.

Welch, Susan, and Donley Studlar. 1990. "Multi-member Districts and the Representation of Women: Evidence from Britain and the United States." Journal of Politics 52, no. 2: 391-412. 